\title{
GRADUATES ARE FROM VENUS, EMPLOYERS ARE FROM MARS: A CROATIAN STUDY ON EMPLOYABILITY*
}

\author{
Ljerka Sedlan-König' ${ }^{1}$ Mia Hocenski² \& Sofija Turjak ${ }^{3}$
}

UDC / UDK : 331.5:338.18(497.5)

JEL classification / JEL klasifikacija: J21, A22

DOI: https://doi.org/10.22598/pi-be/2018.12.2.9

Original scientific paper / Izvorni znanstveni rad

Received / Primljeno:September 19, 2018 / 19. rujna 2018.

Accepted for publishing / Prihvaćeno za tisak: November 30, 2018 / 30. studenoga 2018.

\section{Summary}

Growing demand for higher education and the increasing difficulty graduates' face when looking for and securing appropriate work upon graduation, place heavy emphasis on the importance of an enhanced understanding of what constitutes employability. Interest in graduate employability produces benefits for all stakeholders, including universities, employers and graduates themselves. This comparative study aims to investigate graduates' perceptions of competences and attributes important for employability, and compare these with employers' expectations, for the purpose of raising awareness about the differences. It also aims to understand the extent to which employers are satisfied with HE to train work-ready graduates. This investigation reports on findings from 206 graduate students and 134 employers. Evidence indicates that there is a modest degree of alignment between graduates and employers regarding competences and attributes important for employability. Both groups value willingness to learn and problem-solving skills highly, and agree that practical experience, subject knowledge and use of social networks are not significant for employability. Employers appreciate learning skills, enthusiasm and motivation and intelligence more than graduates do. On the other hand, graduates believe that positive attitude towards change, written communication and public speaking skills substantially contribute

\footnotetext{
The paper was presented at the 3rd International Conference „Business \& Entrepreneurial Economics -BEE2018” which was held in Šibenik from 30 May to 2 June 2018 (www.bee-conference.com)

1 Ljerka Sedlan-König, Assistant Professor, Faculty of Economics, J.J. Strossmayer University, Osijek, Croatia, E-mail: ljerka.koning@efos.hr

2 Mia Hocenski, MA, Teaching and Research Assistant, Faculty of Economics, J.J. Strossmayer University, Osijek, Croatia, E-mail:,mia.hocenski@efos.hr

3 Sofija Turjak, MA., Teaching and Research Assistant, Faculty of Economics, J.J. Strossmayer University, Osijek, Croatia, E-mail: sofija.turjak@efos.hr
} 
to future labor market outcomes. In order to stand apart and gain positional advantage in the labor market, graduates need to be aware of this mismatch and take steps to acquire these competences and attributes outside university, and it is essential that universities adjust their curriculum, assessment methods and pedagogy in partnership with employers in order to minimize the gap between what is expected from and what is delivered through higher education.

Key words: perceptions of employability, university, competences, attributes, graduateness.

\section{INTRODUCTION}

In a volatile, uncertain, complex and rapidly changing environment, the knowledge of an academic subject is no longer sufficient, and graduates need to gain skills which will enhance their employability outcomes. There are few official statements about what graduates are supposed to learn at universities, the perceptions of graduates have been under-investigated, and are rarely compared to those of employers. In order to broaden the understanding of what graduate competences and attributes are critical for employability from both graduates' and employers' perceptions, this comparative study was conducted with the following hypotheses:

H1: Graduates in Croatia recognize competences and attributes important for employability

$\mathrm{H} 2$ : There is a high degree of agreement between the perceptions of employers and graduates regarding employability competences and attributes.

H3: Employers in Croatia are satisfied with how universities educate work-ready graduates

This paper begins with an overview of the literature on graduate employability with particular reference to the distinction between graduateness and employability, which is very often overlooked. The paper then draws on to explore the views of graduates and employers regarding competences and attributes that promote employability. In the next section, the research highlights the level of satisfaction in regard to universities' contribution to the acquisition of these competences and attributes, from employers' and graduates' perspectives. In the final part, conclusions and recommendations are made and a direction for further research is suggested.

\section{LITERATURE REVIEW}

In general terms, employability is defined as having the skills and abilities to find employment, remain in employment or obtain new employment (Hillage and Pollard, 1998; Rothwell and Arnold 2007; Thijssen et al. 2008). The term often comprises a range of individual characteristics that facilitate adaptive behaviors (Fugate et al., 2004,). Yorke and Knight (2006) understand employability as a set of achievements, skills, understandings and personal attributes that make graduates more likely to gain 
employment and be successful in their chosen occupations, which benefits themselves, the workforce, the community and the economy. Alternatively, it can be seen as a function of the labor market context with labor supply and demand determining an individual's employability at any given time (Forrier and Sels, 2003). Contemporary definitions have moved towards a more complex understanding of graduate employability, and emphasize the acquisition of inter-related attributes, skills and competencies that allow the individual to secure and perform well in the workplace.

Graduates' vs. Employers' Views on Employability. Previous research shows that students seek graduateness for the purpose of employability and see their learning as an investment that will give them direct benefits in the labor market (Tomlinson, 2008). Earlier investigations show that although a degree is still seen as significant for employability, university graduates are seeking a much broader range of skills and competencies than those confirmed within the bounds of subject knowledge, i.e. development of skills related to future employment, information technology, research skills, problem-solving skills, and study skills (Glover, Law and Youngman, 2006). This study also indicates that original hopes for the university experience are not being met for the majority of graduates.

From an employer perspective, employability is mainly concerned with ensuring that graduates are capable of contributing to economic competitiveness in a global context (Cranmer, 2006), whereby, employers particularly value generic skills and analytic abilities that promote flexibility and adaptation (Lowden et al., 2011). Literature indicates that employers want graduates who can adapt to the workplace culture, use their abilities and skills to evolve the organization and participate in innovative teamwork. Employers expect graduates to have technical and discipline competences from their degrees but require graduates also to demonstrate a range of broader skills and attributes that include team-working, communication, leadership, critical thinking, problem solving and managerial abilities. (Lowden et al., 2011). Literature shows that employers give high priority to key skills of problem solving, communication, team work, information technology, and self-management (Glover, Law and Youngman, 2002). Along the same lines, Walker (1995) additionally proposes self-awareness as what might be expected from a graduate. Furthermore, Archer and Davison (2008) found that regardless of the size of the company, 'soft skills' were perceived to have more weight than technical skills with employers.

To achieve this, degree programs now tend to focus on the acquisition of two types of skills: critical subject specific knowledge and skills, and transferable knowledge, skills and attitudes (Leckey and McGuigan, 1997; Cox and King, 2006). Transferable skills include oral communication, high level learning skills, problem solving, decision making, and affective skills and traits such as responsibility, a positive attitude, interpersonal skills and the ability to work both in a team and independently (Cassidy, 2006).

By shifting the focus towards graduate employability rather than knowledge acquisition, universities acknowledge their critical role in promoting employability.

Modern Universities and Employability. With the shift towards mass higher education and large numbers of graduates with similar educational profiles competing for 
employment, the purpose and process of HE have changed, as well as the expectations of graduates and employers. The role and the status of higher education qualifications in maximizing one's labor market potential is also changing, since in a congested and increasingly competitive labor market, academic qualifications have a declining role in shaping the employment outcomes of graduates. In part, HE has been predicted upon the value of education for its own sake, but researchers such as Ashton \& Green (1996), Barber \& Sebba (1999) and Robinson (2000) see participation in (higher) education as an investment that yields social and private gains. On the other hand, others challenge the supply-side focus and argue that the rise in university qualifications does not reflect a genuine economic demand for more highly qualified labor and adds little to individuals' human capital, generating growing pressures for individuals to acquire degrees to access employment, thus increasing the number of overqualified graduates for the type of employment they get (Tomlinson, 2008). In such a situation it is not surprising that employers are attributing less importance to HE degrees and placing more importance on personal attributes and skills.

Modern universities need to change further as claims have increasingly been made that academic curriculum should be a vehicle through which competences and attributes are delivered (Fallows \& Steven, 2000). For graduates to be self-reliant and able to take responsibility for their own careers, outcomes of university programs should, apart from knowledge and understanding, include key skills (communication, numeracy, the use of IT and learning how to learn), cognitive skills (such as critical analysis), and subject specific skills (Dearing Committee, 1997, cited in Fallows \& Steven, 2000).

Graduates need to be flexible and prepared for a lifetime of change and development. European Commission has long ago recognized the need to establish a "learning society" which takes account of the rapid changes due to the internationalization of trade, the move towards an information society and developments in science and technology, and which utilizes education and training to provide solutions through a mix of formal qualifications and personal skills. It is university education in particular which has to provide graduates with the skills to be able to operate professionally within the environment required for the "learning society". As a result, several researchers (Lowden et al., 2011; McMurray, 2014; Andrews and Higson, 2008) identify work experience, work placements, internships as the key resource for the development of soft skills and wider employability, it has been shown that work experience increases confidence, produces more rounded individuals and improves graduates' connections to the labor market.

\section{METHODOLOGY}

The main objective of the empirical research was to investigate graduates' perceptions of competences and attributes important for employability, and compare these with employers' expectations, for the purpose of raising the awareness about the differences. It also aims to understand the extent to which employers are satisfied with HE to train work-ready graduates and thus meet their requirements. For this purpose, online 
Graduate Employability Survey was used, which employed open and closed questions, as well as 7-point Likert scales, to indicate the importance participants in the survey place on 36 employability competences and attributes, as well as to determine the extent to which HE contributes to their acquisition, for two shareholder groups: graduates and employers. The list of competences and attributes was comprised based on the surveys conducted previously in Europe by the European Commission (Eurobarometer, 2010) and Winterbotham et al. (2014). T-test was used for determining statistically significant differences.

In total 206 responses by graduate students at Josip Juraj Strossmayer University of Osijek, Croatia were received. Most students attended the Faculty of Economics (117). Others were from Faculty for Educational Sciences (28) and Faculty of Civil Engineering (23), Faculty of Electrical Engineering (4) and the Faculty of Mechanical Engineering (6) while 12 students attended the Department of Physics and 16 students studied at the Faculty of Law. $91.3 \%$ of students studied full-time, while $8.7 \%$ were part-time students. In the sample, $68.4 \%$ were women and $31.6 \%$ are men. The grade point average (GPA) of students in this survey was 3.81 .

Total of 1,647 questionnaires was sent to employers, targeting a broad spectrum of industries and businesses. 134 employers responded (response rate of $8.14 \%$ ). Of the companies surveyed, $34 \%$ were micro companies, $36 \%$ small, $13 \%$ came from medium companies, and $17 \%$ were large organizations. Hence, the research captures the views of employers from both large and small companies. Although the sample is not representative of all enterprises employing graduates in Croatia, it does cover a wide range of branches of economic activity and different sizes (by number of employees) of enterprises. Subsequently, semi-structured interviews with five employers and five graduates were conducted to enquire further into their opinion and needs. The instrument, therefore, provides useful information that can be used for taking action to improve graduate employability in Croatia.

\section{RESULTS AND DISCUSSION}

Interviews conducted with graduates, let us conclude that the distinction between graduateness and employability is only poorly understood by Croatian graduates. Their expectations are that a degree will ensure them a secure and profitable future and that the degree itself guarantees immediate employability. Graduates are rarely aware that they need to develop and refine their competences and attributes in order to adapt to the world of work. Nonetheless, both graduates and employers indicated the importance of a range of competences and attributes that help graduates to be employable (Table 1). 
Table 1: Assessment of Graduates' and Employers' Importance of Employability Skills

\begin{tabular}{|c|c|c|c|c|c|}
\hline $\begin{array}{l}\text { Competences and } \\
\text { attributes }\end{array}$ & $\begin{array}{c}\text { Average } \\
\text { Importance } \\
\text { for } \\
\text { Employers }\end{array}$ & $\begin{array}{l}\text { St. dev. } \\
\text { Importance } \\
\text { for } \\
\text { Employers }\end{array}$ & $\begin{array}{l}\text { Average } \\
\text { Importance } \\
\text { for } \\
\text { Graduates }\end{array}$ & $\begin{array}{c}\text { St.dev. } \\
\text { Importance } \\
\text { for } \\
\text { Graduates }\end{array}$ & $t$ - test \\
\hline Learning skills & 6.11 & 1.250 & 5.95 & 1.168 & $\begin{array}{l}t=-1.304 d f= \\
336 p=0.193\end{array}$ \\
\hline Teamwork & 6.11 & 0.963 & 5.92 & 1.150 & $\begin{array}{l}t=-1.496 d f= \\
336 p=0.136\end{array}$ \\
\hline IT usage & 6.11 & 1.072 & 6.10 & 0.995 & $\begin{array}{l}t=-0.314 d f= \\
336 p=0.894\end{array}$ \\
\hline Subject knowledge & 5.11 & 1.405 & 5.17 & 1.302 & $\begin{array}{l}t=0.615 d f=337 \\
p=0.539\end{array}$ \\
\hline IQ & 6.08 & 1.016 & 5.86 & 1.113 & $\begin{array}{l}t=-1.999 d f=337 \\
p=0.046^{*}\end{array}$ \\
\hline Problem solving & 6.27 & 1.014 & 6.14 & 1.041 & $\begin{array}{l}t=-1.229 d f=338 \\
p=0.220\end{array}$ \\
\hline $\begin{array}{l}\text { Enthusiasm and } \\
\text { motivation }\end{array}$ & 6.25 & 1.014 & 5.91 & 1.114 & $\begin{array}{l}t=-2.909 \mathrm{df}= \\
336 p=0.004^{*}\end{array}$ \\
\hline Willingness to learn & 6.15 & 0.984 & 6.20 & 0.966 & $\begin{array}{l}t=0.633 d f=337 \\
p=0.527\end{array}$ \\
\hline $\begin{array}{l}\text { Strong orientation to } \\
\text { achievement }\end{array}$ & 5.30 & 1.194 & 5.36 & 1.223 & $\begin{array}{l}t=0.449 d f=335 \\
p=0.654\end{array}$ \\
\hline Practical experience & 5.17 & 1.555 & 5.53 & 1.543 & $\begin{array}{l}t=2.268 d f=331 \\
p=0.024^{*}\end{array}$ \\
\hline Public speaking & 5.16 & 1.346 & 5.97 & 1.181 & $\begin{array}{l}t=5.848 d f=338 \\
p=0.000^{*}\end{array}$ \\
\hline $\begin{array}{l}\text { Application of acquired } \\
\text { knowledge }\end{array}$ & 6.05 & 1.168 & 6.09 & 1.275 & $\begin{array}{l}t=0.292 d f=338 \\
p=0.770\end{array}$ \\
\hline $\begin{array}{l}\text { Foreign language } \\
\text { knowledge }\end{array}$ & 6.05 & 1.069 & 6.11 & 1.130 & $\begin{array}{l}t=0.384 d f=338 \\
p=0.701\end{array}$ \\
\hline Achievement in sport & 3.16 & 1.627 & 2.98 & 1.480 & $\begin{array}{l}t=-0.871 d f= \\
262.947 p=0.385\end{array}$ \\
\hline $\begin{array}{l}\text { Establishing and } \\
\text { maintaining interpersonal } \\
\text { contact }\end{array}$ & 6.03 & 0.949 & 5.88 & 1.114 & $\begin{array}{l}t=-1.432 \mathrm{df}= \\
314.038 p=0.153\end{array}$ \\
\hline Diligence & 6.02 & 0.972 & 6.12 & 1.017 & $\begin{array}{l}t=0.893 d f=338 \\
p=0.372\end{array}$ \\
\hline Desire for achievement & 5.98 & 1.088 & 6.01 & 1.183 & $\begin{array}{l}t=0.254 d f=332 \\
p=0.800\end{array}$ \\
\hline $\begin{array}{l}\text { Thinking "outside the } \\
\text { box" and innovativeness }\end{array}$ & 5.94 & 1.051 & 5.92 & 1.259 & $\begin{array}{l}t=-0.194 \mathrm{df}= \\
338 p=0.846\end{array}$ \\
\hline $\begin{array}{l}\text { Positive attitude towards } \\
\text { change }\end{array}$ & 5.94 & 1.021 & 6.13 & 0.928 & $\begin{array}{l}t=1.878 d f=338 \\
p=0.061\end{array}$ \\
\hline Written communication & 5.92 & 0.954 & 5.96 & 1.099 & $\begin{array}{l}t=0.180 d f=338 \\
p=0.857\end{array}$ \\
\hline Work ethics & 5.90 & 1.374 & 5.23 & 1.365 & $\begin{array}{l}t=-4.358 d f= \\
335 p=0.000^{*}\end{array}$ \\
\hline
\end{tabular}


Table 1. Continued

\begin{tabular}{|l|c|c|c|c|l|}
\hline \multicolumn{1}{|c|}{$\begin{array}{c}\text { Competences and } \\
\text { attributes }\end{array}$} & $\begin{array}{c}\text { Average } \\
\text { Importance } \\
\text { for } \\
\text { Employers }\end{array}$ & $\begin{array}{c}\text { St. dev. } \\
\text { Importance } \\
\text { for } \\
\text { Employers }\end{array}$ & $\begin{array}{c}\text { Average } \\
\text { Importance } \\
\text { for } \\
\text { Graduates }\end{array}$ & $\begin{array}{c}\text { St.dev. } \\
\text { Importance } \\
\text { for } \\
\text { Graduates }\end{array}$ & \multicolumn{1}{|c|}{ t - test } \\
\hline Self-confidence & 5.79 & 1.013 & 5.96 & 1.033 & $\begin{array}{l}\mathrm{t}=1.458 \mathrm{df}=337 \\
\mathrm{p}=0.146\end{array}$ \\
\hline Discipline & 5.79 & 1.019 & 5.69 & 1.113 & $\begin{array}{l}\mathrm{t}=-0.746 \mathrm{df}= \\
338 \mathrm{p}=0.456\end{array}$ \\
\hline Opportunity recognition & 5.70 & 1.313 & 5.71 & 1.226 & $\begin{array}{l}\mathrm{t}=0.090 \mathrm{df}=321 \\
\mathrm{p}=0.928\end{array}$ \\
\hline Usage of social networks & 4.68 & 1.608 & 4.89 & 1.481 & $\begin{array}{l}\mathrm{t}=1.468 \mathrm{df}=338 \\
\mathrm{p}=1.43\end{array}$ \\
\hline Taking initiative & 5.66 & 1.154 & 5.48 & 1.151 & $\begin{array}{l}\mathrm{t}=-1.514 \mathrm{df}=337 \\
\mathrm{p}=0.131\end{array}$ \\
\hline Independence & 5.64 & 1.106 & 5.66 & 1.105 & $\begin{array}{l}\mathrm{t}=-0.011 \mathrm{df}= \\
338 \mathrm{p}=0.991\end{array}$ \\
\hline Negotiation skills & 5.57 & 1.326 & 5.89 & 0.994 & $\begin{array}{l}\mathrm{t}=2.293 \mathrm{df}= \\
228.631 \mathrm{p}= \\
0.023^{*}\end{array}$ \\
\hline Work under pressure & 5.57 & 1.226 & 5.53 & 1.313 & $\begin{array}{l}\mathrm{t}=-0.351 \mathrm{df}= \\
337 \mathrm{p}=0.726\end{array}$ \\
\hline Aggression & 2.56 & 1.453 & 2.89 & 1.637 & $\begin{array}{l}\mathrm{t}=1.889 \mathrm{df}=337 \\
\mathrm{p}=0.060\end{array}$ \\
\hline Sense of humor & 4.53 & 1.438 & 4.12 & 1.457 & $\begin{array}{l}\mathrm{t}=-2.526 \mathrm{df}= \\
338 \mathrm{p}=0.012^{*}\end{array}$ \\
\hline $\begin{array}{l}\text { Making judgments } \\
\text { on basis of limited } \\
\text { information }\end{array}$ & 5.46 & 1.356 & 5.60 & 1.147 & $\begin{array}{l}\mathrm{t}=0.985 \mathrm{df}=338 \\
\mathrm{p}=0.352\end{array}$ \\
\hline Critical thinking & 5.38 & 1.233 & 5.36 & 1.191 & $\begin{array}{l}\mathrm{t}=-0.035 \mathrm{df}= \\
337 \mathrm{p}=0.972\end{array}$ \\
\hline Persuasion & 1.201 & 5.73 & 1.088 & $\begin{array}{l}\mathrm{t}=3.086 \mathrm{df}=337 \\
\mathrm{p}=0.002^{*}\end{array}$ \\
\hline
\end{tabular}

${ }^{*} \mathrm{p}$-value is given for T-test on a significance level of 0.05

Employers and graduates agree that willingness to learn and problem solving skills contribute significantly to graduate employability, and this is consistent with previous findings (Rayner and Papakonstantinou, 2015; Prinsley and Baranyai, 2015). In addition to these skills, employers also highlighted the application of relevant knowledge, which is consistent with other/previous findings (Rayner and Papakonstantinou, 2015; Jones, 2009; Nagarajan \& Edwards, 2014; Rae, 2007). This is not surprising, given its connection with higher order thinking skills, such as critical thinking and the likely correlation between these skills and workplace productivity. As expected, both subgroups attributed the lowest values in promoting employability to good looks, achievement in sport and aggressiveness. Apart from that, neither employers nor graduates value the use of social networks, GPA or subject-matter knowledge as particularly important for employability. Interestingly, in the interviews, graduates expressed their belief that a degree in itself enhances employability. 
Although subject-matter knowledge was agreed as an important attribute, a combination of transferable skills, such as team work and good interpersonal and communication skills, was deemed particularly relevant for promoting graduate employability. This is in line with previous research (Andrews and Higson, 2010, Lowden et al., 2011, Ferns, 2012). Willingness to learn ( $\overline{\mathrm{x}} 6.14)$ and learning skills ( $\overline{\mathrm{x}} 6.12)$ were ranked higher in importance by employers than the application of relevant knowledge $(\overline{\mathrm{x}} 6.05)$ and were given significantly higher values than both subject knowledge ( $\overline{\mathrm{x}} 5.08)$ and GPA ( $\overline{\mathrm{x}} 4.03$ ). Furthermore, as many as $98.5 \%$ of employers in our sample would hire the candidate who has had a lower GPA during his studies provided they have acquired good communication skills, show a desire for achievement, possess a high IQ, discipline and work ethics. The low ranking for practical experience in this research is contrary to the broader view, and does not align with previous research (Andrews and Higson, 2010; Prinsley and Baranyai, 2015). Croatian employers value willingness to learn (on the job) as much more important for doing well in the labor market, although in job applications candidates are usually asked to document some work experience.

On the other hand, a t-test has shown several significant differences at the significance level of 0.05 in the perception of importance of certain competences and attributes. For example: practical experience, public speaking and persuasion are considered more important by graduates than by employers. More importantly, significant differences have been detected regarding IQ, work ethics as well as with enthusiasm and motivation, which employers regard as more important than graduates. It is interesting to notice that employers regard the use of humor as more important than graduates do. In conclusion, Hypothesis 1 has been proven as graduates recognize competences and attributes important for employability, but there is little synergy between the perceptions of employers and graduates regarding the value of employability competences and attributes, and thus Hypothesis 2 has been rejected.

Employers and graduates agree that HE contributes the least to humor, aggressiveness and achievement in sports (Table 2).

Table 2: Comparison of Graduates' and Employers' Satisfaction with the Contribution of HE to the Development of Entrepreneurial Skills

\begin{tabular}{|l|r|r|r|r|l|}
\hline \multicolumn{1}{|c|}{$\begin{array}{c}\text { Competences and } \\
\text { attributes }\end{array}$} & $\begin{array}{c}\text { Average } \\
\text { Contribution } \\
\text { for } \\
\text { Employers }\end{array}$ & $\begin{array}{c}\text { Stan. Dev. } \\
\text { Contribution } \\
\text { for } \\
\text { Employers }\end{array}$ & $\begin{array}{c}\text { Average } \\
\text { Contribution } \\
\text { for } \\
\text { Graduates }\end{array}$ & $\begin{array}{c}\text { St Dev. } \\
\text { Contribution } \\
\text { for } \\
\text { Graduates }\end{array}$ & T - Test \\
\hline Learning skills & 4.08 & 1.719 & 4.26 & 1.711 & $\begin{array}{l}\mathrm{t}=0.937 \mathrm{df}=336 \\
\mathrm{p}=0.349\end{array}$ \\
\hline $\begin{array}{l}\text { Establishing and } \\
\text { maintaining interpersonal } \\
\text { contact }\end{array}$ & 4.08 & 1.729 & 4.77 & 1.363 & $\begin{array}{l}\mathrm{t}=3.409 \mathrm{df}= \\
232.808 \mathrm{p}=0.001^{*}\end{array}$ \\
\hline Work under pressure & 4.18 & 1.677 & 4.92 & 1.757 & $\mathrm{t}=3.780 \mathrm{df}=333$ \\
$\mathrm{p}=0.000$
\end{tabular}


Table 2. Continued

\begin{tabular}{|c|c|c|c|c|c|}
\hline $\begin{array}{l}\text { Competences and } \\
\text { attributes }\end{array}$ & $\begin{array}{c}\text { Average } \\
\text { Contribution } \\
\text { for } \\
\text { Employers } \\
\end{array}$ & $\begin{array}{c}\text { Stan. Dev. } \\
\text { Contribution } \\
\text { for } \\
\text { Employers }\end{array}$ & $\begin{array}{c}\text { Average } \\
\text { Contribution } \\
\text { for } \\
\text { Graduates }\end{array}$ & $\begin{array}{c}\text { St Dev. } \\
\text { Contribution } \\
\text { for } \\
\text { Graduates }\end{array}$ & $\mathrm{T}$ - Test \\
\hline $\begin{array}{l}\text { Positive attitude towards } \\
\text { change }\end{array}$ & 3.89 & 1.746 & 4.98 & 1.569 & $\begin{array}{l}t=5.782 d f= \\
255.73 p=0.000^{*}\end{array}$ \\
\hline Usage of social networks & 3.86 & 1.755 & 4.38 & 1.654 & $\begin{array}{l}t=2.752 d f=336 \\
p=0.006^{*}\end{array}$ \\
\hline Independence & 3.84 & 1.747 & 4.54 & 1.500 & $\begin{array}{l}t=3.810 \mathrm{df}= \\
248.563 p=0.000^{*}\end{array}$ \\
\hline Subject knowledge & 4.81 & 1.589 & 4.99 & 1.363 & $\begin{array}{l}\mathrm{t}=0.998 \mathrm{df}= \\
248.727 \mathrm{p}=0.319\end{array}$ \\
\hline Desire for achievement & 3.81 & 1.724 & 4.66 & 1.600 & $\begin{array}{l}t=4.701 d f=334 \\
p=0.000^{*}\end{array}$ \\
\hline Self-confidence & 3.73 & 1.667 & 4.28 & 1.540 & $\begin{array}{l}t=3.183 d f=333 \\
p=0.002^{*}\end{array}$ \\
\hline Work ethics & 3.72 & 1.774 & 4.15 & 1.706 & $\begin{array}{l}t=2.215 d f=334 \\
p=0.027^{*}\end{array}$ \\
\hline Critical thinking & 3.70 & 1.615 & 4.31 & 1.572 & $\begin{array}{l}t=3.405 d f=334 \\
p=0.001^{*}\end{array}$ \\
\hline $\begin{array}{l}\text { Strong orientation to } \\
\text { achievement }\end{array}$ & 3.66 & 1.685 & 4.24 & 1.543 & $\begin{array}{l}t=3.277 d f=336 \\
p=0.001^{*}\end{array}$ \\
\hline IT usage & 4.64 & 1.603 & 5.08 & 1.424 & $\begin{array}{l}t=2.650 \mathrm{df}= \\
255.503 p=0.009^{*}\end{array}$ \\
\hline Negotiation skills & 3.64 & 1.686 & 4.17 & 1.629 & $\begin{array}{l}t=2.900 d f=335 \\
p=0.004^{*}\end{array}$ \\
\hline Sense of humor & 2.61 & 1.532 & 2.63 & 1.629 & $\begin{array}{l}t=0.114 d f=336 \\
p=0.910\end{array}$ \\
\hline $\begin{array}{l}\text { Enthusiasm and } \\
\text { motivation }\end{array}$ & 3.60 & 1.696 & 4.21 & 1.667 & $\begin{array}{l}t=3.279 d f=333 \\
p=0.001^{*}\end{array}$ \\
\hline Persuasion & 3.58 & 1.534 & 3.99 & 1.470 & $\begin{array}{l}t=2.471 d f=335 \\
p=0.014^{*}\end{array}$ \\
\hline Teamwork & 4.56 & 1.627 & 5.28 & 1.416 & $\begin{array}{l}t=4.264 \mathrm{df}= \\
250.116 \mathrm{p}=0.000^{*}\end{array}$ \\
\hline $\begin{array}{l}\text { Foreign language } \\
\text { knowledge }\end{array}$ & 4.55 & 1.584 & 4.16 & 1.733 & $\begin{array}{l}t=-2.016 d f=336 \\
p=0.040^{*}\end{array}$ \\
\hline $\begin{array}{l}\text { Application of acquired } \\
\text { knowledge }\end{array}$ & 3.54 & 1.530 & 3.84 & 1.685 & $\begin{array}{l}t=1.665 d f=336 \\
p=0.097\end{array}$ \\
\hline Aggression & 2.54 & 1.565 & 2.38 & 1.645 & $\begin{array}{l}t=-0.874 d f= \\
335 p=0.383\end{array}$ \\
\hline Achievement in sport & 2.54 & 1.469 & 2.36 & 1.506 & $\begin{array}{l}t=-1.088 d f=333 \\
p=0.278\end{array}$ \\
\hline Practical experience & 3.52 & 1.777 & 3.86 & 2.051 & $\begin{array}{l}t=3.003 \mathrm{df}= \\
256.624 p=0.003^{*}\end{array}$ \\
\hline $\begin{array}{l}\text { Thinking "outside the } \\
\text { box" and innovativeness }\end{array}$ & 3.49 & 1.790 & 4.14 & 1.697 & $\begin{array}{l}t=3.341 d f=335 \\
p=0.001^{*}\end{array}$ \\
\hline Public speaking & 4.47 & 1.566 & 5.50 & 1.430 & $\begin{array}{l}t=6.219 d f=335 \\
p=0.000^{*}\end{array}$ \\
\hline
\end{tabular}


Table 2. Continued

\begin{tabular}{|c|c|c|c|c|c|}
\hline $\begin{array}{c}\text { Competences and } \\
\text { attributes }\end{array}$ & $\begin{array}{c}\text { Average } \\
\text { Contribution } \\
\text { for } \\
\text { Employers }\end{array}$ & $\begin{array}{l}\text { Stan. Dev. } \\
\text { Contribution } \\
\text { for } \\
\text { Employers }\end{array}$ & $\begin{array}{c}\text { Average } \\
\text { Contribution } \\
\text { for } \\
\text { Graduates }\end{array}$ & $\begin{array}{c}\text { St Dev. } \\
\text { Contribution } \\
\text { for } \\
\text { Graduates }\end{array}$ & $\mathrm{T}$ - Test \\
\hline $\begin{array}{l}\text { Making judgments } \\
\text { on basis of limited } \\
\text { information }\end{array}$ & 3.45 & 1.646 & 4.31 & 1.448 & $\begin{array}{l}t=4.049 d f= \\
237.84 p=0.000^{*}\end{array}$ \\
\hline Taking initiative & 3.45 & 1.604 & 4.06 & 1.475 & $\begin{array}{l}t=3.580 d f=336 \\
p=0.000^{*}\end{array}$ \\
\hline Opportunity recognition & 3.43 & 1.612 & 4.24 & 1.584 & $\begin{array}{l}t=4.479 d f=322 \\
p=0.000^{*}\end{array}$ \\
\hline Written communication & 4.39 & 1.679 & 4.88 & 1.549 & $\begin{array}{l}t=2.731 d f= \\
263.116 p=0.007^{*}\end{array}$ \\
\hline IQ & 3.39 & 1.743 & 4.17 & 1.668 & $\begin{array}{l}t=4.089 d f=335 \\
p=0.000^{*}\end{array}$ \\
\hline Discipline & 4.37 & 1.555 & 4.51 & 1.634 & $\begin{array}{l}t=0.802 d f=336 \\
p=0.423\end{array}$ \\
\hline Willingness to learn & 4.37 & 1.744 & 4.95 & 1.573 & $\begin{array}{l}t=3.003 d f= \\
256.624 p=0.003^{*}\end{array}$ \\
\hline Diligence & 4.34 & 1.639 & 4.63 & 1.611 & $\begin{array}{l}t=1.644 d f=334 \\
p=0.101\end{array}$ \\
\hline
\end{tabular}

${ }^{*} \mathrm{p}$-value is given for T-test on a significance level of 0.05

The two subgroups express similar levels of satisfaction regarding subject knowledge, diligence, learning skills, practical experience and application of required knowledge. Otherwise, little agreement is observed in the satisfaction of employers and graduates with the contribution of $\mathrm{HE}$ to the development of competences and attributes that promote employability (Figure 1).

Employers are most satisfied with university contribution to subject knowledge and use of IT, and graduates value the contribution to public speaking skills and team work the most. Values for satisfaction in case of employers are lower than those expressed by graduates for all competences and attributes, except for foreign language skills - employers seem to be more satisfied than graduates regarding the acquisition of these skills. Employers' satisfaction with the extent to which education at universities contribute to development of employability competences and attributes is in general moderate ( $\overline{\mathrm{x}} 3.84$, on the scale of 7 ), and a significant mismatch between competences and attributes required and the ones developed during $\mathrm{HE}$ has been observed. Therefore, Hypothesis 3 can be only partially confirmed. Between the importance in promoting employability and satisfaction with $\mathrm{HE}$ contribution to the development of these competences, statistically significant differences have been observed for all employability competences and attributes, with the only exception of subject knowledge.

In general, no significant differences in mean values for the importance of employability competences and attributes (given by employers and graduates) have been perceived ( $\overline{\mathrm{x}} 5.54$ and $\overline{\mathrm{x}} 5.56$, respectively). But the differences in mean values are signif- 
icant regarding the satisfaction with HE contribution, as employers, overall, expressed significantly lower levels of satisfaction $(\overline{\mathrm{x}} 3.84)$ than graduates $(\overline{\mathrm{x}} 4.34)$. It is also interesting that values for importance are significantly higher than values for satisfaction: 5.54 and 3.84, respectively (for employers); and 5.56 and 4.34, respectively (for graduates). These findings are in line with what has been previously reported (Ferns, 2012).

Figure 1: Differences regarding HE contribution to development of employability competences and attributes

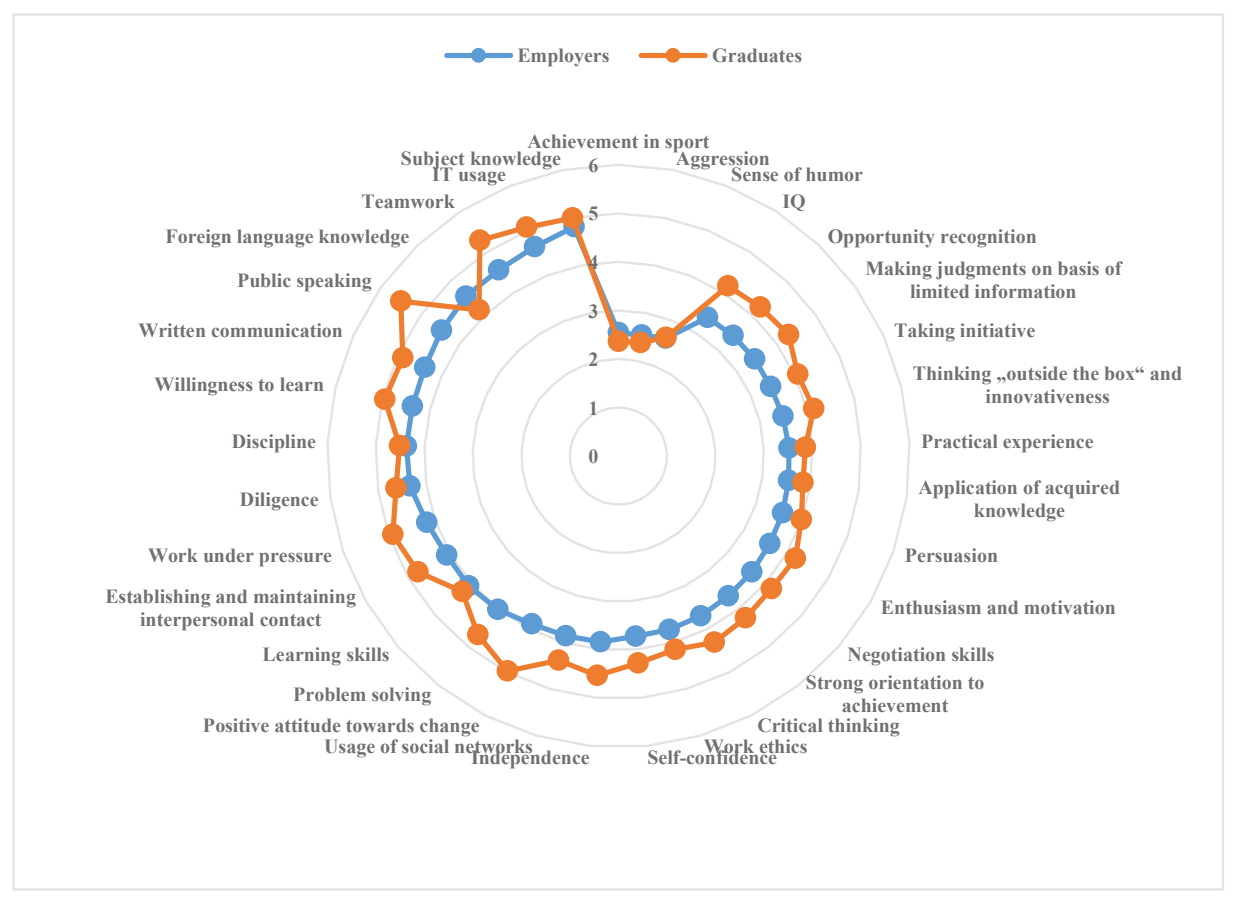

\section{CONCLUSION}

This research has shown that graduates and employers differ in their priorities regarding employability competences and attributes, and universities need to understand that and take it into account when designing courses.

Employers in this research expect graduates to have a degree along with techni$\mathrm{cal}$ and discipline competences, but require a range of transferable competences and attributes that include problem solving skills, enthusiasm and motivation, willingness to learn and learning skills, team work and use of IT, general intelligence, foreign languages and application of knowledge and skills. Although job related competences continue to form the basis of a strong academic education, universities need to develop graduates' transferable skills. These findings pose questions around curriculum design, teaching strategies and assessment processes. 
The results highlight the mismatch between what employers expect and what graduates believe promotes their employability. Clearly, an effort has to be made to minimize the discrepancy. Graduates have to be informed about what employers expect from future employees, about the emphasis on life-long skills rather than short term job readiness, as well as about high quality work placements. There are several approaches that could be adopted by universities to improve employability, among others improvement in curriculum, change in university pedagogy, designing valid means of assessing student employability upon graduation, as well as making sure that qualification and assessment methods recognize a wide range of appropriate learning outcomes. Some other recommendations can be read from the interviews with employers, such as: placing employability at the center of universities' strategic planning, widening access to work placements as an effective way of providing graduates with relevant employability competences and attributes, and promoting real partnership between universities and employers to develop measures that contribute to graduate employability.

In order to increase employability, graduates need to assume primary responsibility for acquiring competences and attributes valued by current and prospective employers (Van Buren III 2003; Fugate et al., 2004; McQuaid and Lindsay 2005), but opinion is also expressed in favor of a partnership between employers and graduates regarding boosting employability competences and attributes. Of course, competences can be fostered by further training and coaching (Glover, Law and Youngman, 2002), but, as the interviews with the employers revealed, employers prefer to employ work-ready graduates. If graduates take into account the employers preferences, a balance can be achieved to ensure that employers will have a competent workforce, and graduates will have the necessary competences and attributes to respond to the needs of the world of work. Support through both formal and informal education is needed to meet the needs of students. Universities should ensure that competences and attributes valuable for employability are embedded within the curriculum for all disciplines but it is too optimistic to expect that each graduate develops these competences and attributes during the course of studies. Therefore, extracurricular activities have to be acknowledged. University is not the only place where students nowadays acquire knowledge and skills for life. Students now learn in many different contexts, outside university. For most students, university is part-time experience and there are many other opportunities for learning, for example through work placement, volunteering, participating in student clubs and organizations, personal development. This paper challenges students to assume a holistic view of education by recognizing that education extends far beyond a classroom.

This is an exploratory study and is designed as a foundation for future research into the assessment processes, models of partnerships between employers and universities, and extracurricular activities.

\section{REFERENCES:}

1. Rothwell, A. and Arnold, J. (2007) Self-perceived employability: development and validation of a scale, Personnel Review, Vol. 36 Issue: 1, pp.23-41, Available from: https://doi.org/10.1108/00483480710716704. [Accessed 17/02/18]. 
2. Andrews, J. and Higson, H. (2008). Graduate employability, 'soft skills' versus 'hard' business knowledge: A European study. Higher education in Europe, 33(4), pp. 411-422.

3. ARCHER, W. and DAVISON J. (2008) Graduate employability: What do employers think and want? London, the Council for Industry and Higher Education (CIHE).

4. ASHTON, D. and GREEN, F. (1996) Education, Training and the Global Economy. London: Edward Elgar.

5. BARBER, M. and SEBBA, J. (1999) Reflections on Progress Towards a World Class Education System, Cambridge Journal of Education, 29, pp. 183-193.

6. CASSIDY, S. (2006). Developing employability skills: Peer assessment in higher education. Education and Training, 48(7), 508-517.

7. COX, S., and KING, D. (2006). Skill sets: An approach to embed employability in course design. Education and Training, 48(4), 262-274.

8. CRANMER, S. (2006). Enhancing graduate employability: Best intentions and mixed outcomes. Studies in Higher Education, 31(2), 169-184.

9. EUROBAROMETER (2010), Employers' Perception of Graduate Employability, Survey of the European Commission's Eurobarometar

10. FALLOWS, S., and STEVEN C. (2000) Building employability skills into the higher education curriculum: a university-wide initiative, Education+ training 42.2 pp.7583.

11. FERNS, S. (2012) Graduate employability: Teaching staff, employer and graduate perceptions. 2012 Australian Collaborative Education Network National Conference. p. 77.

12. FORRIER, A., and SELS, L. (2003). The concept of employability: A complex mosaic. International Journal of Human Resources Development and Management, 3(20), pp. 102-124.

13. FUGATE, M., KINICKI, A. J., and ASHFORTH, B. E. (2004). Employability: A psycho-social construct, its dimensions, and applications. Journal of Vocational Behaviour, 65, pp. 14-38.

14. GLOVER, D., LAW, S., AND YOUNGMAN, A. (2002). Graduateness and Employability: student perceptions of the personal outcomes of university education." Research in post-compulsory education 7.3: pp. 293-306.

15. HILlAGE, J., and POLLARD, E. (1998). Employability: Developing a framework for policy analysis. DFEE. London: Department for Education and Employment.

16. JONES, A. (2009). Re-disciplining generic attributes: The disciplinary context in focus. Studies in Higher Education, 34(1), pp. 85-100.

17. LECKEY, J. F., \& MCGUIGAN, M. A. (1997). Right tracks-Wrong rails: The development of generic skills in higher education. Research in Higher Education, 38(3), pp. 365-378. 
18. LOWDEN, K., HALL, S., ELLIOT, D., \& LEWIN, J. (2011). Employers' perceptions of the employability skills of new graduates. London: Edge Foundation.

19. MCMURRAY, S., DUTTON, M., MCQUAID, R., and RICHARD, A. (2016). Employer demands from business graduates. Education+ Training, 58(1), pp.112-132.

20. MCQUAID, R. W., and LINDSAY, C. (2005). The concept of employability. Urban Studies, 42(2), pp. 197-219.

21. NAGARAJAN, S., and EDWARDS, J. (2014). Is the graduate attributes approach sufficient to develop work ready graduates? Journal of Teaching and Learning for Graduate Employability, 5(1), pp. 12-28.

22. PRINSLEY, R., \& BARANYAI, K. (2015). STEM skills in the workforce: What do employers want? Occasional Paper Series. Canberra, Australia: Office of the Chief Scientist

23. RAE, D. (2007). Connecting enterprise and graduate employability: Challenges to the higher education culture and curriculum? Education + Training, 49(8/9), pp. 605-619.

24. RAYNER, G. \& PAPAKONSTANTINOU, T. (2015). Student perceptions of their workplace preparedness: Making work-integrated learning more effective. Asia-Pacific Journal of Cooperative Education,16(1) pp. 13-24.

25. ROBINSON, P. (2000) Measuring the Knowledge Economy: employment and qualifications, in D. Robertson (Ed.) The Knowledge Economy. London: Routledge.

26. THIJSSEN, G. L., VAN DER HEIJDEN, B. I. J. M., and ROCCO, T. S. (2008). Toward the employability link model: Current employment transition to future employment perspectives. Human Resource Development Review, 7(2), pp.165-183.

27. TOMLINSON, M. (2008). 'The degree is not enough': students' perceptions of the role of higher education credentials for graduate work and employability. British journal of sociology of education, 29(1), pp.49-61.

28. VAN BUREN III, H. J. (2003). Boundary-less careers and employability obligations. Business Ethics Quarterly, 13(2), pp.131-149.

29. WALKER, L. (1995) Institutional Change Towards an Ability-based Curriculum in Higher Education. Sheffield: Employment Department.

30. WINTERBOTHAM M., VIVIAN D., SHURY J., DAVIES B., KIK, G (2014) The UK Commission's Employer Skills Survey 2013: UK Results, Evidence Report 81 Rotherham UKCES 2014, Available from: https:/www.gov.uk/government/uploads/system/uploads/attachment_data/file/327492/evidence-report-81-ukces-employer-skills-survey-13-full-report-final.pdf, [Accessed 22/01/18].

31. YORKE, M and KNIGHT, P (2006) Embedding Employability into the Curriculum. Learning and Employability Series One. York: Higher Education Academy 


\title{
DIPLOMCI SU S VENERE, POSLODAVCI S MARSA: HRVATSKA STUDIJA ZAPOŠLJIVOSTI*
}

\author{
Ljerka Sedlan-König ${ }^{4}$, Mia Hocenski ${ }^{5}$ \& Sofija Turjak ${ }^{6}$
}

\section{Sažetak}

Sve veća potražnja za visokim obrazovanjem i sve veće poteškoće diplomaca prilikom traženja posla i zapošljavanja nakon diplome stavile su veliki naglasak na važnost boljeg razumijevanja sastavnih dijelova zapošljivosti. Bavljenje zapošljivošću ima koristi za sve dionike, kako za sveučilišta, tako i za poslodavce i same diplomce. Ova komparativna studija ima za cilj istražiti percepciju diplomaca o kompetencijama i kvalitetama važnim za zapošljivost, te usporediti ih s očekivanjima poslodavaca, kako bi se podigla svijest o razlikama. Također se želi istražiti koliko su poslodavci zadovoljni visokim obrazovanjem diplomanata spremnih za tržište rada. Ovo istraživanje predstavlja odgovore 206 apsolvenata $i 134$ poslodavca. Rezultati istraživanja pokazuju kako postoji skroman stupanj slaganja između diplomaca i poslodavaca oko kompetencija i kvaliteta važnih za zapošljivost. Obje grupe jako cijene spremnost za učenje i rješavanje problema te se slažu kako praktično iskustvo, znanje o određenoj temi i korištenje društvenih mreža nisu značajni za zapošljivost. Poslodavci više od diplomaca cijene vještine učenja, entuzijazam, motivaciju i inteligenciju. S druge strane, diplomci vjeruju kako na buduće rezultate na tržištu rada značajno utječu otvorenost prema promjeni, pisana komunikacija i vještine javnog govorenja. Kako bi se istaknuli i bili u prednosti na tržištu rada, diplomci moraju biti svjesni ovog nerazmjera te poduzeti korake kako bi izvan sveučilišta stekli tražene kompetencije i kvalitete. Također je potrebno da sveučilišta u suradnji s poslodavcima prilagode svoj kurikulum, metode ocjenjivanja te pedagoški pristup, kako bi se smanjio raskorak izmedu onog što se od diplomaca očekuje na tržištu rada i onog što dobivaju kroz visoko obrazovanje.

Ključne riječi: percepcija zapošljivosti, sveučilište, kompetencije, kvalitete, diplomiranost (graduateness)

JEL klasifikacija: J21, A22

\footnotetext{
Rad je prezentiran na 3. Međunarodnoj konferenciji „Business \& Entrepreneurial Economics -BEE2018” koja je održana u Šibeniku od 30. svibnja do 2. juna 2018 (www.bee-conference.com)

4 Dr. sc. Ljerka Sedlan-König, docent, Ekonomski fakultet, Sveučilište J.J.Strossmayer, Osijek, Hrvatska, E-mail: ljerka.koning@efos.hr

${ }_{5}$ Mia Hocenski, mag.educ.philol.germ.et.mag.educ.philol.angl, asistent, Ekonomski fakultet, Sveučilište J.J.Strossmayer, Osijek, Hrvatska, E-mail: mia.hocenski@efos.hr

${ }^{6}$ Sofija Turjak, mag.oec., asistent, Ekonomski fakultet, Sveučilište J.J.Strossmayer, Osijek, Hrvatska, E-mail: sofija.turjak@efos.hr
} 